\title{
Electromyographic activity of shoulder muscles during exercises performed with oscillatory and non-oscillatory poles
}

\author{
Atividade eletromiográfica dos músculos do ombro durante exercícios \\ executados com hastes oscilatória e não oscilatória
}

Camilla Z. Hallal',2, Nise R. Marques 1,2, Sarah R. D. Silva',3, Jaap V. Dieën4, Mauro Gonçalves',5

\begin{abstract}
Background: Pain and dysfunction of the shoulder complex are commonly found physiotherapy practice. These musculoskeletal abnormalities are related to instability and inadequate kinematic function, that depend on the integrity of the muscle tissues. Thus, to enhance the results of exercise therapies, and prevent and attenuate pain and dynfunction, the use of oscillatory pole has been implemented in clinical practice. Objectives: The purpose of this study was to analyze the electromyographic (EMG) activity of shoulder stabilizing muscles during exercises performed with an oscillatory and a non-oscillatory pole. Methods: Twelve female volunteers, aged 20.4 years \pm 1.9 , participated in this study. EMG data were collected from upper trapezius (UT), lower trapezius (LT) and middle deltoid (MD) during three different exercises with an oscillatory and a non-oscillatory pole. The EMG signals were analyzed in the time domain through the calculation of Root Mean Square (RMS). The RMS values were normalized by the peak value obtained over all trials for each muscle. Statistical analysis was performed with repeated measures ANOVA and post-hoc of Bonferroni tests. Results: The EMG activity of UT, LT and MD muscles were significantly higher with the oscillatory pole than the non-oscillatory pole (all $p<0,001)$. There were no significant differences in the activation of these muscles between exercises. Conclusion: The results of the present study indicated that the oscillatory pole does require higher activation of the shoulder muscles and therefore, may be useful in the training of the shoulder complex.
\end{abstract}

Key words: electromyography; shoulder; biomechanics; exercise; vibration.

\section{Resumo}

Contextualização: A dor e a disfunção no complexo articular do ombro é comumente encontrada na prática fisioterapêutica. Essas anormalidades musculoesqueléticas estão relacionadas à instabilidade e inadequado funcionamento cinemático, que dependem da integridade dos tecidos musculares. Assim, no sentido de prevenir e reabilitar esses sintomas, o uso da haste oscilatória vem sendo implantado para melhorar os resultados de técnicas cinesioterapêuticas. Objetivos: Analisar a atividade eletromiográfica (EMG) dos músculos que estabilizam a articulação do ombro durante a realização de exercícios com haste oscilatória e haste não-oscilatória. Métodos: Participaram do estudo 12 voluntárias com idade de 20,4 1,9 anos. Os dados EMG foram coletados nos músculos trapézio superior (TrS), trapézio inferior ( $\mathrm{Trl}$ ) e deltoide médio (DM) durante três diferentes exercícios realizados com haste oscilatória e haste não-oscilatória. O sinal EMG foi analisado no domínio do tempo pelo cálculo do Root Mean Square (RMS). Os valores de RMS foram normalizados pelo valor de pico obtido em todas as tentativas por cada músculo. A análise estatística foi feita com os testes ANOVA para medidas repetidas e post-hoc de Bonferroni. Resultados: A atividade EMG dos músculos TrS, Trl e DM foi significativamente maior nos exercícios com haste oscilatória do que com haste não-oscilatória (todos $p<0,001$ ). Não foram significativas as diferenças na ativação desses músculos entre os exercícios. Conclusão: Os resultados do presente estudo indicaram que a haste oscilatória requisitou maior atividade EMG dos músculos do ombro e, assim, pode ser um instrumento útil no treinamento desses músculos.

Palavras-chave: eletromiografia; ombro; biomecânica; exercício; vibração.

Received: 04/12/2009 - Revised: 05/05/2010 - Accepted: 26/10/2010

\footnotetext{
Biomechanics Laboratory, Universidade Estadual Paulista (UNESP), Rio Claro, SP, Brazil

${ }^{2}$ Faculty of Science and Tecnology, UNESP, Presidente Prudente, SP, Brazil

${ }^{3}$ School of Physical Education and Sport, Universidade de São Paulo (USP), Ribeirão Preto, SP, Brazil

${ }^{4}$ Faculty of Human Movement Science, VU University Amsterdam, Amsterdam, Netherlands

${ }^{5}$ Bioscience Institute, UNESP, Rio Claro, SP, Brazil

Correspondence to: Mauro Gonçalves, Avenida: 24-A, 1515, Bela Vista, CEP: 13506-900, Rio Claro, SP, Brazil, email: maurog@rc.unesp.br
} 


\section{Introduction : $:$.}

The shoulder joint complex has a large range of motion and is frequently affected by pain and injury ${ }^{1,2}$. The muscles around this joint are responsible for maintaining the shoulder stability and provide adequate kinematic functioning. Among these muscles the medial deltoid (MD) stabilizes the gleno-humeral joint, and the upper and lower trapezium (UT and LT) stabilize the scapulothoracic joint ${ }^{3}$. Therefore, an impaired muscle function has been associated with injuries such as bursitis, tendinoses and joint dislocation ${ }^{47}$.

Since shoulder muscle function may guide the prescription of training and prevention of shoulder complex disorders, many studies have evaluated muscle function using surface electromyography $(\mathrm{EMG})^{5-9}$. De Luca ${ }^{10}$, in his classic study, showed that the number of active motor units has an important contribution to the EMG amplitude signal, although there is no direct relationship between EMG amplitude and force. However, a higher EMG activity is not always desirable, such as in the case of exercises for shoulder stabilization, which a lower UT EMG activity is desirable to prevent and attenuate shoulder complex disturbancess ${ }^{8}$.

Physical therapy, specifically, kinesiotherapy, has been reported as an important treatment modality for shoulder instability. Kinesiotherapy exercises include the use of tools such as elastic bands, cuff weights, isokinetic dynamometer and oscillatory pole, and is used to improve patients outcomes $^{11-16}$.

Oscillatory pole is an instrument, generally with $150 \mathrm{~cm}$ in length and $0.8 \mathrm{~kg}$, that provide oscillation through rhythmic movements of the upper limb. The occilatory frequency of the pole is responsible for providing resistance during exercises ${ }^{16}$. Exercising with this instrument has been reported to be useful to train shoulder muscle function, since the oscillatory pole is reactive, i.e., using the law of inertia to provide resistance to exercise $^{17}$. Thus, the higher the frequency and oscillation amplitude of the pole, the greater the destabilization force in the body, which in turn requires higher levels of muscle activation to maintain stability ${ }^{17,18}$. Also, the oscillation of the hand-held pole is thought to require rapidly varying eccentric and concentric muscular contractions in the upper extremity, which creates equilibrium between stability and mobility ${ }^{18}$.

Lister et al. ${ }^{19}$, compared the electromyography of should muscles during shoulder abduction movement while using Thera-Band ${ }^{\circledR}$, cuff weights or oscillatory pole, and concluded that oscillatory poles produced the highest EMG activity. However, in an eight-week shoulder internal and external rotation strengthening program, no differences between exercising with flexible pole and elastic band were found. Also, this study had several limitations such as an unequal distribution of men and women between groups and the lack of control of the type of physical exercises subjects performed outside the study ${ }^{16}$.

Despite the frequent use of the oscillatory pole in training and rehabilitation of shoulder muscles, only a few studies evaluating this equipment, have been conducted. The few that are available were primarily in men and did not compare the effects of different arm positions in the EMG activity of shoulder muscle stabilizers ${ }^{2}$. Therefore, the effects of an oscillatory and a non-ocillatory pole on the electromyographic (EMG) activity of shoulder muscles during different exercises were compared. Our hypotheses were that exercising with oscillatory pole would lead to greater activity of the studied muscles than exercising with non-oscillatory pole and that the type of exercise would not affect which muscles are primarily recruited.

\section{Methods ::}

\section{Participants}

Participants were twelve females, recruited from a university setting, aged $20.4 \pm 1.9$ years, right-handed, healthy and without musculoskeletal injuries or upper limb pain 6 months prior to the study. Participants signed a written consent form and the study was approved by Research Ethics Committee of Universidade Estadual Paulista, Rio Claro, SP, Brazil (Approval ETTIC 050/2009).

\section{Protocol}

All procedures were completed in two days, separated by a minimum of 24 and maximum of 72 hours. On the first day, the volunteer was familiarized with the experimental procedures, the exercises and both poles. On the second day, the exercises with the oscillatory pole $\left(\right.$ Flexibar $\left.^{\circledR}\right)$ and non-oscillatory pole (made especially for the study) were performed, in a randomly assigned order for all exercises conditions. Both poles had the same mass ( $800 \mathrm{~g}$ ) and length $(150 \mathrm{~cm})$.

Three exercises with different positions of the upper limbs and pole were performed: (I) approximately $90^{\circ}$ degrees of shoulders flexion and pole parallel to the floor (Figure 1A); (II) approximately $180^{\circ}$ degreesof shoulders flexion and pole parallel to the floor (Figure 1B); and (III) approximately $90^{\circ}$ degrees of right upper limb flexion and pole perpendicular to the floor (Figure 1C). A target was positioned in front of the volunteers to position the arm in approximately $90^{\circ}$ of shoulder flexion and a visual feedback helped volunteers maintain this position during the exercise (Figure 1A). 
All exercises were performed for 15 seconds, with a rest period of 60 seconds after each exercise. The rhythm of the pole movements was controlled by a metronome set at $300 \mathrm{bpm}$. The motion of the pole was primarily achieved by flexion and extension of the elbow (Figure 2).

\section{Kinematic data}

Kinematic analysis were conducted to verify the metronome efficiency to maintain the same pole frequency in all exercises. Thus, markers were attached to the central grip and the extremities of the poles. A reflector with a lamp of $300 \mathrm{~W}$ and a camera with image capture rate of $30 \mathrm{fps}$ were positioned $5 \mathrm{~m}$ of the volunteers at $50 \%$ of the height of the participant.

The kinematic data analysis was performed using Vicon Peak 9.0 (Peak Motus ${ }^{\circledR}$ ) during five seconds (fifth and tenth seconds) of the exercises. The displacements of the markers on the central grip and extremities of the poles were used to calculate the frequency of the pole motions.
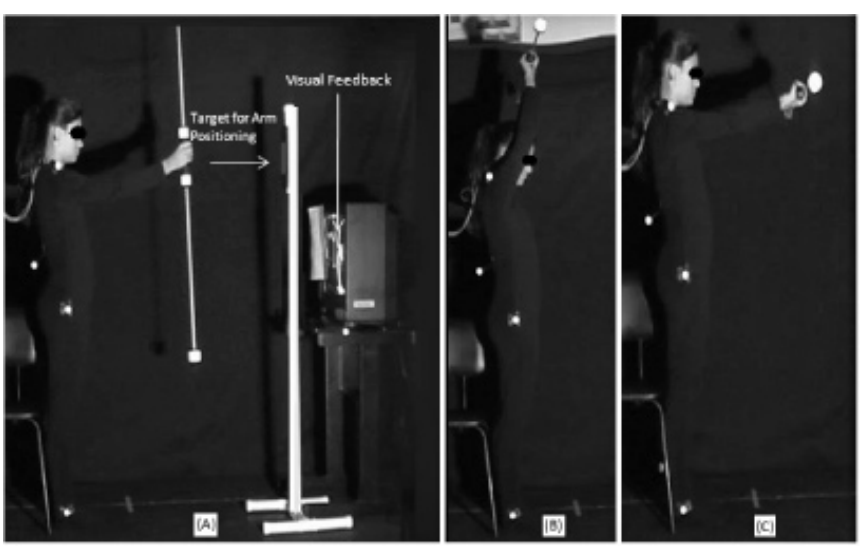

Figure 1. (A) exercise I; (B) exercise II; (C) exercise III.

\section{Electromyography}

$\mathrm{Ag} / \mathrm{AgCl}$ electrodes (Meditrance ${ }^{\circledR}$ ) with capture area of $1 \mathrm{~cm}$ were used in a bipolar configuration with an interelectrode distance of $2 \mathrm{~cm}$. Electrodes were positioned over the right: UT, at $50 \%$ of the distance between the acromium and the spinous process of $\mathrm{C} 7$; LT, at $2 / 3$ on the line from the trigonum spinea to the 8 th thoracic vertebra; and $\mathrm{MD}$, at the greatest bulge of the muscle on the line between the acromium and lateral epicondyle ${ }^{20}$. The ground electrode was placed on the right acromium. Before electrode placement, the skin was prepared by shaving, abrading with sand paper and cleaning the area with alcohol ${ }^{21}$.

The EMG signal was recorded with a sixteen-channel Myoresearch electromyography $\left(\right.$ Noraxon $^{\circledR}$ ) and its specific software MRXP 1.07 (Noraxon $\left.{ }^{\circledR}\right)$. Signals were amplified with a total gain of 2000 times (20 times in the sensor and 100 times in the amplifier), band-pass filtered (20-500 Hz) and stored at a sample rate of 1000 samples/s.

\section{Data analysis}

Analysis custom routines were developed in Matlab for the EMG signal. Data collected between the fifth and the tenth second of each exercise were analyzed. The signal was processed in the time domain to calculate the Root Mean Square (RMS) over windows of $250 \mathrm{~ms}$. The RMS values were normalized by the peak value obtained for each muscle considering all exercises and both poles. PASW Statistic $17.0\left(\mathrm{SPSS}^{\circledR}\right)$ was used to perform repeated measures ANOVAs for each muscle with exercise and pole as independent variables. Post hoc Bonferroni tests were used. For all statistics tests the significance level was set at $\mathrm{p}<0.05$.
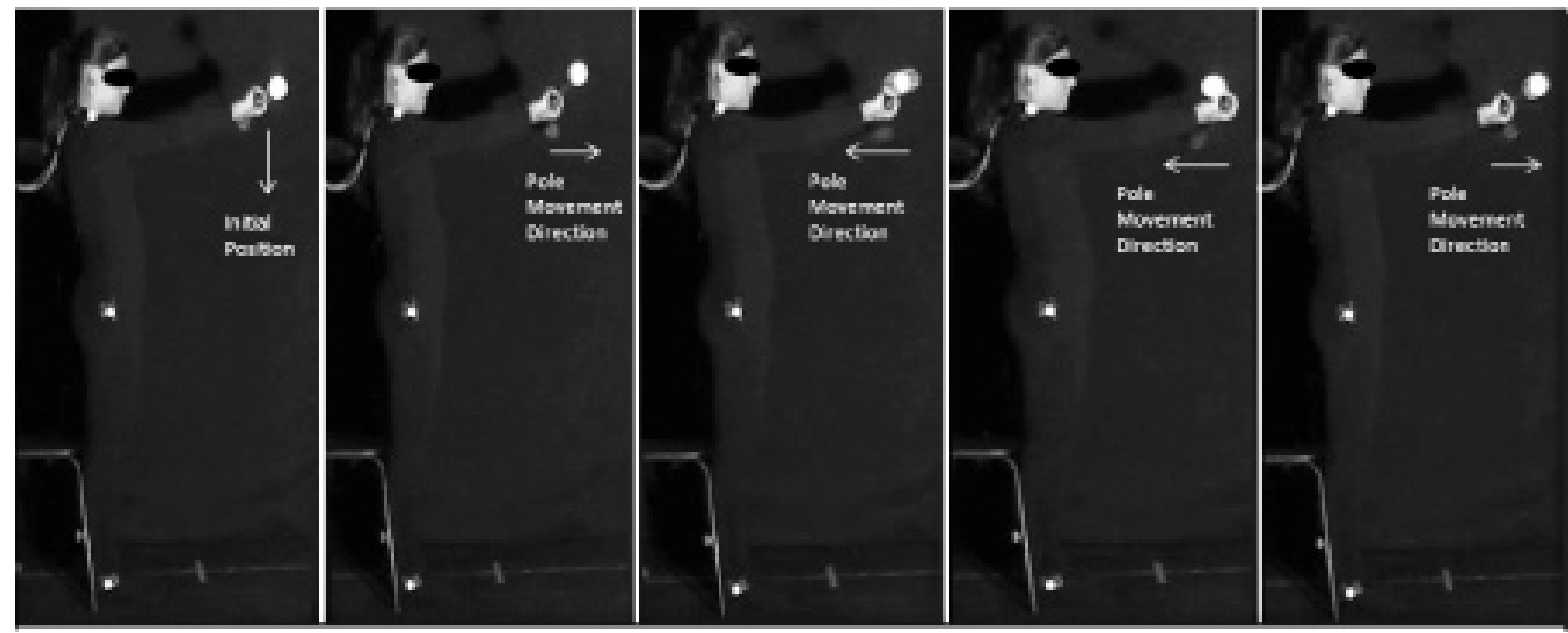

Figure 2. Typical example of exercise I performed with flexible and rigid poles. 

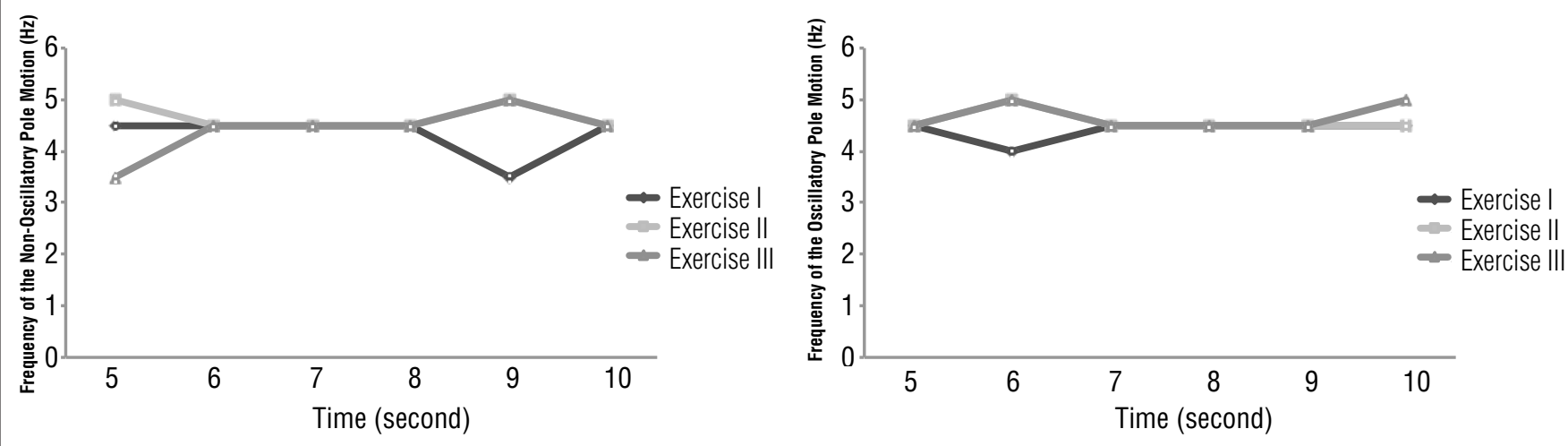

Figure 3. Typical example of the frequency of rigid and flexible pole movements.

\section{Results : :}

No significant differences between movement frequencies were found between exercises on both poles conditions (Figure 3).

In all exercises, the EMG activity of UT, LT and MD muscles were higher during the exercises performed with the oscillatory pole than with non-oscillatory pole (Figure 4; all $\mathrm{p}<0.001$ ).

The type of exercise had limited effect on the EMG activity of the muscles studied and no significant differences between the exercises were found (Figure 5). In addition, no interaction effects were found.

\section{Discussion $: \because$.}

Adequate functioning of shoulder stabilizers muscles are important to prevent pain and injury ${ }^{22}$. Thus, in physical therapy, oscillatory pole has been widely used as an auxiliary instrument to improve shoulder muscles physical capacities ${ }^{23}$.

While the effects of vibration on the human body have been studied for many years, its used in training and rehabilitation has only been implemented recently ${ }^{24}$. Vibration can be applied directly to the muscles and tendons, by specific stimulators, or on the whole body, by vibrating platforms, and finally by using an oscillatory pole or blade ${ }^{25,26}$. Training with an oscillatory pole is different from the other forms of vibration training, because the frequency is low, about $4.5 \mathrm{~Hz}$, and vibrations are not produced by external forces, but by muscular contractions $\mathrm{s}^{17,18}$.

Several mechanisms could lead to an increase in muscular activity during vibration training. Firstly, small changes in muscle fiber length, which could activate muscle spindles and increase the excitation of motor neurons, through the tonic

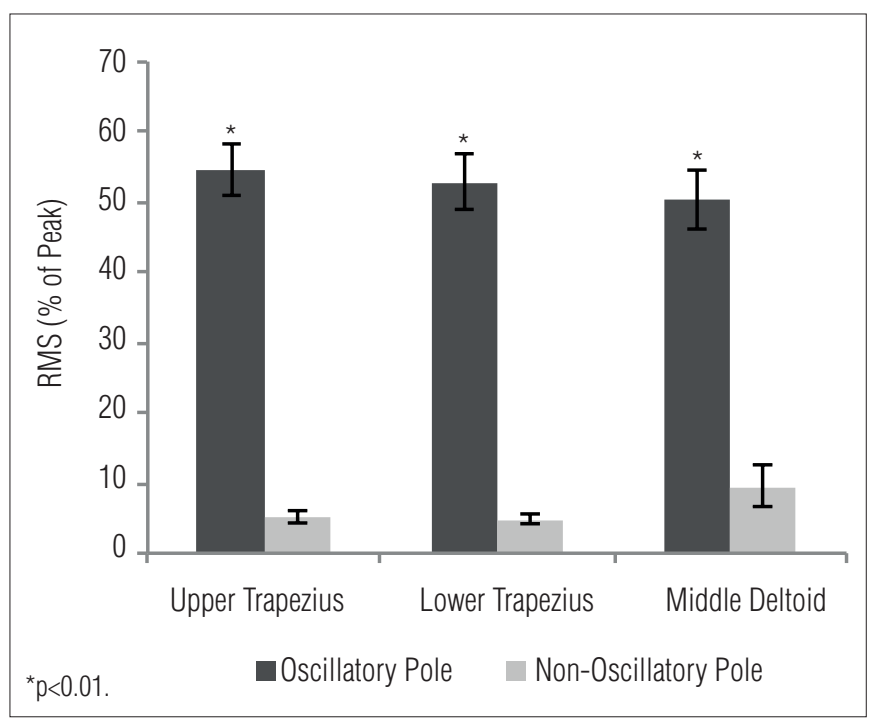

Figure 4. Upper trapezius (UT), lower trapezius (LT) and middle deltoid (MD) RMS values (\%peak) for each of the two poles averaged over the exercise performed.

vibration reflex. However, the frequencies of the pole movement identified in this study were unlikely to be high enough to cause such effects ${ }^{27}$. Second, the forces induced by the resonating pole's oscillations may perturb shoulder equilibrium and as such solicit stabilizing activity of the shoulder muscles over and above the level that would be induced by the motion of the arm. It has been suggested that exercises with oscillatory pole require more muscle activation, which causes an increase in the stiffness and stability of the shoulder complex ${ }^{28,29}$.

In the present study, the exercises performed with the oscillatory pole substantially increased the activation of UT, LT and MD muscles. Although the relationship between EMG amplitude and force was not direct, when an improvement of 


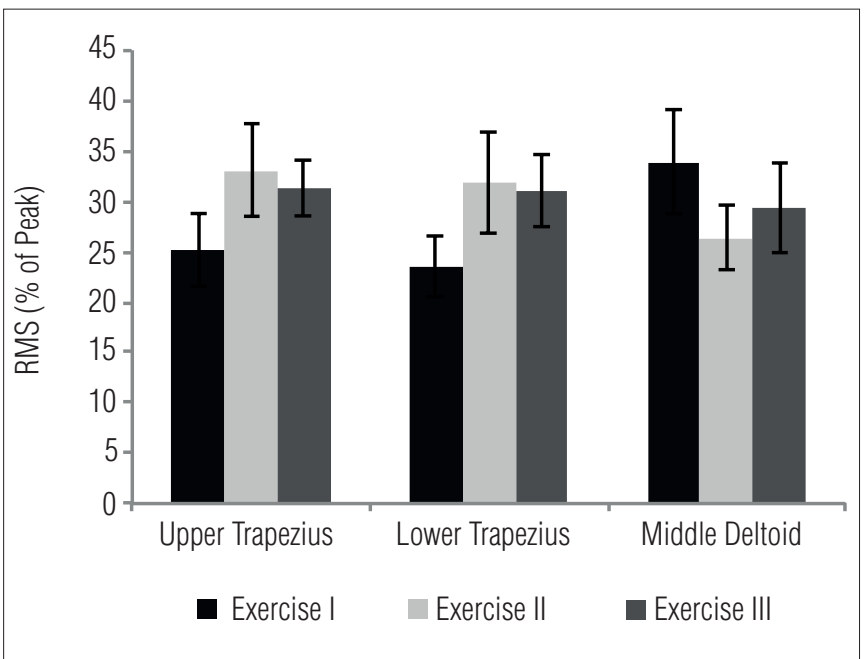

Figure 5. Upper trapezius (UT), lower trapezius (LT) and middle deltoid (MD) RMS values (\% of peak) for each of the exercises averaged over the two pole conditions.

the overload occured, it resulted in an increase in the number of active motor units ${ }^{10}$. Accordingly, the use of exercise with flexible pole could promote a muscular overload, which is an important factor to be considered in exercise prescription.

An important consideration about the EMG data analysis is the presence of motion artifact at the signal. According to Fratini et al. ${ }^{30}$, the higher the vibration frequency, the higher the effect of the motion artifact in the EMG signal. Thus, in this study, with whole body vibration performed by vibratory platform in a frequency of $12.8 \mathrm{~Hz}$, the difference between filtered RMS value and non-filtered RMS value could vary approximately $1-12 \%$, depending on the muscle. However, the effect of vibration frequencies lower than $10 \mathrm{~Hz}$ in the EMG signal has yet to been determined in literature. This limits the decision making about the use of a specific filter to remove this type of artifact. In our study, no specific filter for motion artifact was used; however, cautions in the electrode and fixation of cables were done to avoid noise from oscillation.

A limitation of the present study is that only 3 muscles were tested (MD, UT and LT), which are only a few of the muscles responsible for stabilizing the shoulder complex. Therefore, further studies should compare EMG activity during exercises with oscillatory pole, of rhomboids, serratus and cuff rotator muscles to provide a better understanding of the effects of this type of exercises in the rehabilitation of shoulder joint. The comparison between exercises with oscillatory and non oscillatory pole is also limited, given that the use of exercises with a simple non-oscillatory pole being moved back and forth is not used in rehabilitation. Thus, it is necessary to compare the effects of the oscillatory pole on muscle activity with an usual therapeutic tools.

This study tested a group of young, healthy and physically fit women only. So, generalization of these findings to other groups, such as elderly and sedentary individuals, should be considered with care.

The exercises performed did not strongly differ in terms of muscle activation. Comparable biomechanical demands resulted in similar EMG activity ${ }^{31}$. However, the small sample size may also have reduced the power of the test, which limited the analysis comparing the EMG activity between the three exercises performed. Thus, different exercises with the oscillatory pole, more specific targeting the UT, LT and MD muscles, could be studied. Sánches-Zuriaga et $\mathrm{al}^{32}$, analyzed trunk muscles EMG during the use of oscillatory blade with different blade orientations in two different exercises, and found that the type of exercise determined which group of muscles were recruited.

\section{Conclusion : : :}

The results of this study demonstrated important considerations for the prescription of exercises with oscillatory pole. We concluded that the oscillatory pole can be an efficient equipment to enhance motor unit recruitment during exercise, although comparable biomechanical demands resulted in similar EMG activity. Furthermore, this study had only a singlesession evaluation and the results refer to an immediate effect of oscillatory pole exercise. Therefore, the implementation of follow-up studies is suggested in order to verify the training effect with oscillatory pole exercises in the physical capacity of the shoulder muscles.

\section{References: : :}

1. Smith LK, Weiss EL, Don Lehmkuhl L. Brunnstom's clinical kinesiology. 5th ed. Philadelphia: F.A. Davis Company; 1996.

2. Reinold MM, Macrina LC, Wilk KE, Fleisig GS, Dun S, Barrentine SW, et al. Electromyographic analysis of the supraspinatus and deltoid muscles during 3 common rehabilitation exercises. J Athl Train. 2007;42(4):464-9.
3. Nordin M, Frankel VH. Basic biomechanics of the musculoskeletal system. 3th. Philadelphia: Lippincot Willians \& Wilkins; 2001.

4. Oliveira AS, Freitas CMS, Monaretti FH, Ferreira F, Noguti R, Bérzin F. Avaliação eletromiográfica de músculos da cintura escapular e braço durante exercícios com carga axial e rotacional. Rev Bras Med Esporte. 2006;12(1):11-5. 
5. Brum DPC, Carvalho MM, Tucci HT, Oliveira AS. Avaliação eletromiográfica de músculos da cintura escapular e braço durante a realização de exercícios com extremidade fixa e carga axial. Rev Bras Med Esporte. 2008;14(5):466-71.

6. Uhl TL, Carver TJ, Mattacola CG, Mair SD, Nitz AJ. Shoulder musculature activation during upper extremity weigth-bearing exercise. J Orthop Sports Phys Ther. 2003;33(3):109-17.

7. Kibler WB. The role of the scapula in athletic shoulder function. Am J Sports Med. 1998;26(2): 325-37.

8. Cools AM, Dewitte V, Lanszweert F, Notebaert D, Roets A, Soetens B, et al. Rehabilitation of scapular muscle balance: which exercises to prescribe. Am J Sports Med. 2007;35(10): 1744-51.

9. Kuechle DK, Newman SR, Itoi E, Niebur GL, Morrey BF, An KN. The relevance of the moment arm of shoulder muscles with respect to axial rotation of the glenohumeral joint in four positions. Clin Biomech. 2000;15(5):322-9.

10. De Luca C. The use of surface electromyography in biomechanics. J Appl Biomech. 1997;13(2):135-63.

11. Green S, Buchbinder R, Hetrick S. Physiotherapy interventions for shoulder pain. Cochrane Database Syst Rev. 2003;(2):CD004258.

12. Cleland J, Durall CJ. Physical therapy for adhesive capsulitis: Systematic review. Physiotherapy. 2002;88(8):450-7.

13. Hughes CJ, Hurd K, Jones A, Sprigle S. Resistance properties of Thera-Band tubing during shoulder abduction exercise. J Orthop Sports Phys Ther. 1999;29(7):413-20.

14. Baydar M, Akalin E, El O, Gulbahar S, Bircan C, Akgul O, et al. The efficacy of conservative treatment in patients with full-thickness rotator cuff tears. Rheumatol Int. 2009;29(6):623-8.

15. Lin HC, Li JS, Lo SF, Shih YF, Lo CY, Chen SY. Isokinetic characteristics of shoulder rotators in patients with adhesive capsulitis. J Rehabil Med. 2009;41(7):563-8.

16. Sugimoto D, Blanpied P. Flexible foil exercise and shoulder internal and external rotation strength. J Athl Training. 2006;41(3):280-5

17. Moreside JM, Vera-Garcia FJ, McGill SM. Trunk muscle activation patterns, lumbar compressive forces, an spine stability when using the bodyblade. Phys Ther. 2007;87(2):153-63.

18. Anders C, Wenzel B, Scholle HC. Cyclic upper body perturbations caused by a flexible pole: influence of oscillation frequency and direction on trunk muscle co-ordination. J Back Musculoskelet Rehabil. 2007;20(4):167-75
19. Lister JL, Del Rossi G, Ma F, Stoutenberg M, Adams JB, Tobkin S, et al. Scapular stabilizer activity during Bodyblade®, cuff weigths, and Thera-Band® use. J Sport Rehabil. 2007;16(1): 50-67.

20. Hermens JH, Freriks B, Disselhorst-Klug K, Rau G. Development of recommendations for SEMG sensors and sensor placement procedures. J Electromyogr Kinesiol. 2000;10(5):361-74.

21. Gonçalves M, Barbora FSS. Análise de parâmetros de força e resistência dos músculos eretores da espinha lombar durante a realização de exercício isométrico em diferentes níveis de esforço. Rev Bras Med Esp. 2005;11(2):102-14

22. Johnson GR, Pandyan AD. The activity in the three regions of the trapezius under controlled loading conditions - an experimental and modeling study. Clin Biomech (Bristol, Avon). 2005;20(2):155-61

23. Schulte RA, Warner C. Oscillatory devices accelerate proprioception training. Clin Biomech. 2001;6:85-91.

24. Delecluse C, Roelants M, Verschueren S. Strenght increase after whole-body vibration compared with resistance training. Med Sci Sports Exerc. 2003;35(6):1033-41.

25. Jordan MJ, Norris SR, Smith DJ, Herzog W. Vibration training: an overview of the area, training consequences, and future considerations. J Strength Cond Res. 2005;19(2):459-66.

26. Shinohara M. Effects of prolonged vibration on motor unit activity and motor performance. Med Sci Sports Exerc. 2005;37(12):2120-5

27. Bosco C, Cardinale M, Tsarpela 0 . Influence of vibration on mechanical power and electromyogram activity in human arm flexor muscles. Eur J Appl Physiol Occup Physiol. 1999;79(4):306-11.

28. Seroussi RE, Wilder DG, Pope MH. Trunk muscle electromyographic and whole body vibration. J Biomech. 1989;22(3):219-29.

29. Duchateau J, Enoka RM. Neural adaptations witch chronic activity patterns in able-bodied humans. Am J Phys Med Rehabil. 2002;81(11 Suppl):S17-27.

30. Fratini A, Cesarelli M, Bifulco P, Romano M. Relevance of motion artifact in electromyography recordings during vibration treatment. J Electromyogr Kinesiol. 2009;19(4):710-8.

31. Cardinale M, Bosco C. The use of vibration as an exercise intervention. Exerc Sport Sci Rev. 2003;31(7):3-7.

32. Sánchez-Zuriaga D, Vera-Garcia FJ, Moreside JM, McGill SM. Trunk muscle activatin patterns and spine kinematics when using an oscillating blade: influence of different postures and blade orientations. Arch Phys Med Rehabil. 2009;90(6):1055-60. 